\title{
AGAMA DAN FILSAFAT PERENNIAL PERSPEKTIF SEYYED HOSSEIN NASR
}

Oleh: Abu Sahrin

\begin{abstract}
Perennial Philosophy (Philosophy Perennis) is the most monumental work of Seyyed Hossein Nasr's thought, and with that thought he succeeded in bringing together the religion of Islam, philosophy and Science which he said would remain forever. As a universal religion Islam is a continuation of the religions that have been revealed to the apostles, starting Adam a.s. arrived at the Prophet Muhammad. the whole religion is called al-Islam, which in essence is a total surrender to God.

Even so according to Nasr, even though Islam and western religions and traditions have equality in several respects, Muslims must not take Western values and views for granted. There must be cech and balance, there must be criticism and auto criticism regarding Western ontology, especially dealing with modern science. The importance of criticizing the basis of modern science ontology, according to Nasr, is because ontology is the most fundamental part of the development of science.
\end{abstract}

Keywords: Religion, Philosophy Perennis, and Seyyed Hossein Nasr

\section{Prolog}

Filsafat Perennial (Philosophy Perennis) merupakan karya paling monumental dari pemikiran Seyyed Hossein Nasr, dan dengan pemikiran itu pula ia berhasil mempertemukan antara agama Islam, filsafat dan Sains yang menurutnya akan tetap abadi untuk selamanya. Sebagai agama universal Islam merupakan kelanjutan dari agama-agama yang pernah diturunkan kepada rasul-rasul, mulai Adam a.s. sampai kepada Nabi Muhammad saw. keseluruhan agama itu disebut dengan al-Islam yang intinya adalah penyerahan secara totalitas kepada Tuhan. Apabila yang menjadi inti adalah penyerahan diri kepada Tuhan, maka pada dasarnya semua agama-agama monoteistis mengaku hanya menyerahkan diri kepada Tuhan saja. Ini berarti penyeraha diri (al-islam) merupakan ajaran agama yang abadi dan berlaku sepanjang masa (religion perennis).

Istilah Religion perennis (agama perennial) atau Philosophy perennis (filsafat perennial) pertama kali digunakan oleh Frichof Schuon) dalam 
bukunya Islam and The Perennial Philosophy. yang oleh Seyyeh Hossein Nasr dipandang sebagai metafisika Universal, terkait dengan religion perennis atau religion cordis - menurut Shuon adalah istilah yang digunakan untuk agama wahyu atau agama samawi ${ }^{1}$ kata lain yang digunakan untuk istilah religion prennis adalah esoterisme, namun istilah ini lebih sering digunakan oleh Muhammad Isa Nuruddin (Prichouf Schuon), walaupun kedua istilah itu mempunyai kata dan arti yang berbeda, namun, namun pada prinsifnya mempunyai jiwa yang sama yaitu titik temu agama-agama, dengan penekanan yang berbeda. Perjumpaannya adalah; bahwa filsafat keabadian adalah suatu prinsif yang ditemukan dalam berbagai agama dan tradisi, misalnya semua manusia senang dengan kejujuran, keadilan, kebenaran, dan nilai-nilai itu ada dalam setiap agama. Hanya saja ketika membicarakan apa yang benar dan apa yang salah maka esoterisme tak membahasnya lagi karena sudah menjadi bagian eksoterisme. Sedang dalam filsafat perennial, sesuatu yang dianggab abadi dalam agama dan tradisi apabila keabadian itu juga ditemukan dalam agama dan tradisi lain.

Begitu pun menurut Nasr, walaupun Islam dan agama dan tradisi barat mempunyaai persamaan dalam beberapa hal, namun umat Islam tidak boleh menerima begitu saja nilai dan pandngan-pandangan Barat. Harus ada cech and balance harus ada kritk dan auto kritik menyangkut ontology Barat, apalagi berhadapan dengan sains moderm. Pentingnya melakukan kitik terhadap dasar ontologi sains modem, menurut Nasr, dikarenakan ontologi merupakan bagian paling fundamental dalam bangunansuatu ilmu. Dasar ontologi menjadi penentu pola bangunan epistemologi, yangselanjutnya menentukan ke arah mana ilmu itu bergerak. Dari sinilah munculberagam faham dalam ilmu pengetahuan.

Asumsi demikian mengisyaratkan bahwa setiap pengetahuan secara a priori menerima adanya realitas sebagai objek pengetahuan. Oleh karenanya, pandangan tentang realitas merupakan dasar dari seluruh bangunan ilmu. Tidaklah mengherankan, dalam dunia keilmuan, selalu adau paya ilmiah yang disebut metode, yakni cara kerja untuk dapat memahami objek yang menjadi sasaran ilmu yang sedang dikaji. Objeklah yang menentukan metode,bukannya sebaliknya.Dengan demikian, ketika seorang peneliti memasuki bidang agama, maka ia akan berhadapan dengan suatu fenomena yang muncul lantaran penerapan nilai-nilai, keyakinan-keyakinan, dan perasaan-perasaan. Kesemuanya ini melibatkan kedalaman paling inti dari fikiran manusia. Agama, tentu saja, ekspresi-ekspresi yang dapat diamati, pranata-pranata yang dapat diukur atau

${ }^{1}$ Untuk lebih jelasnya tentang religion perennis atau religion cordis silahkan dibaca buku ; Islam dan Filsafat Ferennial karya Frichof Shuon (Muhammad Isa Nuruddin). Mizan, Bandung 1995. 
manifestasi-manifestasi yang terlembagakan, namun makna ekspresi-ekspresi, pranatapranata, dan manifestasi-manifestasi inilah yang menjadi pokok persoalan utama dalam kajian-kajian agama

\section{Biografi Seyyed Hossein Nasr}

Seyyed Hossein Nasr di lahirkan pada tanggal 7 april 1933 di Teheran Iran, dari keluarga ulama dan fisikawan tradisional. ${ }^{2}$ Sebagaimana umumnya dalam masyarakat tradisional, sebagai anak-anak ia memulai pendidikannya secara informal pada usia dini, dirumah ayahnya. 3 Sebagai praktisi pengobatan yang berpengalaman baik dalam pengobatan tradisional maupun modern, juga sekaligus sebagai salah seorang sarjana sastra dan pendidik terkenal. ${ }^{4}$ Ia juga merupakan guru Nasr pertama yang mengajarinya secara tradisional membaca dan menghafal surat-surat dalam al-Qur'an dan syairsyair Persia terkemuka. Pengaruh pendidikan tradisional Nasr terhadap perkembangan intelektualnya sangat penting. Bagi anak tradisional ini, Barat berarti wilayah ilmu pengetahuan dan teknologi, yang disitu keberhasilan dan kemajuan terletak. Ia menhawali pendidikannya di Peddie School di Highstown, New Jersey, pada 1946, di mana ia menyelesaikan tingkat kedelapan yang sebelumnya telah ia jalani di Teheran. Ia kemudian melanjutkan pendidikan menengahnya hingga lulus dari Peddie dengan penghargaan dan sebagai pemberi sambutan atas nama kelasnya pada 1950. Pada tahun yang sama, ia juga mengawali pendidikan tingginya dalam bidang fisika dan matematika di salah satu universitas Amerika paling bergengsi, M.I.T, di mana ia menjadi murid terkemuka, dengan menunjukkan bakatnya dalam studi sains. Ia memilih mempelajari sains, dan terutama fisika, karena ia pikir sains akan memenuhi keinginannya. Nasr sendiri menulis:

Saya tertarik dalam sains sejak masih muda sekali. Saya pikir melalui sains saya dapat mengungkapkan hakikat sesuatu; itulah yang ada di dalam benak saya. Bagaimana pun, saya merasa bahwa ini bukanlah yang saya cari, bahwa saya tidak akan memahami mengapa-nya sesuatu, atau bahkan bagaimana-nya sesuatu. ${ }^{5}$ Pada 1951, Nasr yang berusia delapan belas tahun, tertarik mencari cara lain untuk mempelajari hakikat sesuatu dan dunia alam. Tuntutan metafisis ini, yang mengantarnya ke bidang yang lebih luas, lagilagi mendorongnya ke studi filsafat dan sejarah sains, meskipun secara formal ia masih belajar fisika dan matematika di M.I.T.

\footnotetext{
${ }^{2}$ Nasr, 'Inques of the Eternal Sophia', vol 5-6, 1980, h. 133.

${ }^{3}$ Adnan Aslan, Menyingkap Kebenaran, h. 20

${ }^{4}$ Nasr, Quest of the Eternal, h. 113.

${ }^{5}$ Nasr, Tradisional Cosmology and Modern Science. Parabola, VIII no. 4, 1983, h. 20
} 
Pada awal tahun lima puluhan, Nasr bergabung denagn kelompok kecil mahasiswa fisika, matematika dan kimia yang ingin mempertanyakan dasardasar peradaban Barat. Ia merupakan anggota yang aktif, sehingga dalam satu dekade kemudian diindentifikasi oleh Theodore Roszak sebagai 'counterbudaya'. Dengan melibatkan diri dalam kelompok ini, Nasr berusaha malampui batas-batas pemikiran Barat dan mempelajari ajaran-ajaran Timur. Lagi-lagi, Di Santilana-lah yang menunjukkan kepada Nasr karya-karya R. Guenon yang menandai titik dalam kehidupan inteletualnya, dan membawa ke filsafat perennial.

Sebelum berangkat ke Harvard untuk studi doktornya, Nasr sudah akrab dengan filsafat perennial yang kemudian menjadi komitmennya sepanjang hidup. Setelah memperoleh beasiswa dari M.I.T. pada 1954, Nasr memasuki Harvard. Setelah satu periode mempelajari geologi dan geofisika di sana dan menyelesaikan tingkat M.A., ia melakukan proyek riset dalam bidang sejarah sains di bawah bimbingan Sir Hamilton Gibb, H.A. Wolfson dan I.B. Cohen. Secara inteletual Nasr sangat aktif; ia tidak ingin kehilangan setiap kesempatan yang dapat memperluas wawasannya dan memperdalam pengetahuannya. Ia bertemu dengan sarjana-sarjana, semisal D.Z. Suzuki dan Sh. Hisamutsu, dan mengambil banyak manfaat dari perpustakaan unik Coomaraswarmy yang, bagi Nasr, merupakan route menuju kebijakan Timur.

Apresiasi Nasr yang mendalam terhadap guru-guru tradisional Muslim, baik Abad Pertengahan maupun kontemporer, dan penerimaannya yang tidak kritis terhadap otoritas tradisi itu, telah mengantarkannya menjadi 'cermin' bagi kebijakan tradisional, atau di hadapan sinar kebenaran. Ia lebih menyukai peran mediator, yang membuatnya bukan sebagai pemikir yang benar-benar orisinal. Burckardt adalah intelektual lain yang banyak mengilhami Nasr. Burckardt yang banyak menulis tentang esoterisme Islam, seni suci dan, terutama, seni Islam merupakan tokoh utama mazhab sophia perennis. Nasr sering surat menyurat dan bertemu dengannya beberapakali.Pada 1958, ketika ia berusia dua puluh tahun, Nasr merampungkan desertasi doktornya dalam bidang Kosmologi Islam, yang kemudian diterbitkan dengan judul, An Introduction to Islamic Cosmological Doctrine: Conception of Nature and Methods Used for Its Study by the Ikhwan ash-Shafa, al-Biruni and Ibn Sina (1964).

Pada tahun yang sama, setelah tiga belas tahun di Amerika, Nasr kembali ke Iran dengan gelar Ph.D. dari Harvard, juga dengan apresiasi baru terhadap tradisi Islam yang hidup dan dengan kesadaran utuh terhadap kesalahan-kesalahan dan penyimpangan-penyimpangan yang terjadi di dunia 
modern dan, kenyataannya, telah semakin jelas sepanjang dua dekade yang lalu. Di samping intensitas keilmuannya, Nasr juga orang yang suka kerja. Selama periode 20 tahun di Iran, Nasr hidup secara profesional. Ia menjadi Profesor Sains dan Filsafat di Universitas Teheran. Ia juga ikut serta di hampir setiap dewan pendidikan di negeri tersebut. Menjadi Dekan dan Wakil Konselor Universitas Teheran dan Presiden Universitas Aryamehr. Di samping kegiatan-kegiatan tersebut, Nasr juga memainkan peran penting dalam membangun kampus universitas yang besar di kota Isfahan, iran. Pada 1974, ia mendirikan Iranian Academy of philosophy dan bertindak sebagai Direktur pertamanya.

\section{Karya Seyyed Hossein Nasr}

Nasr adalah penulis lebih dari lima puluh buku dan lima ratus artikel (beberapa yang dapat ditemukan dalam jurnal, Studi Perbandingan Agama di) pada topik-topik seperti metafisika tradisional, ilmu pengetahuan Islam, agama dan lingkungan, tasawuf, dan filsafat Islam. Di bawah ini adalah sebagian besar karya Dr Nasr dalam bahasa Inggris (tidak dalam urutan tertentu), termasuk terjemahan, volume diedit, dan Festschriften untuk menghormatinya; yang paling terkenal adalah:

- The HarperCollins Study Quran

- In Search of the Sacred

- Islam in the Modern World

- Islam and the Plight of Modern Man

- Ideals and Realities of Islam

- An Introduction to Islamic Cosmological Doctrines

- Knowledge and the Sacred

- Islamic Life and Thought

- Islamic Art and Spirituality

- Sufi Essays

- Sadr al-Din Shirazi and His Transcendent Theosophy, 2nd edition

- A Young Muslim's Guide to the Modern World

- The Need for a Sacred Science

- Traditional Islam in the Modern World

- Man and Nature: The Spiritual Crisis in Modern Man

- The Islamic Intellectual Tradition in Persia, edited by Mehdi Aminrazavi

- The Garden of Truth: The Vision and Promise of Sufism, Islam's Mystical Tradition

- Three Muslim Sages 
- Science and Civilization in Islam

- Islamic Science: An Illustrated Study

- Religion and the Order of Nature

- Muhammad: Man of God

- Islamic Studies: Essays on Law and Society, the Sciences, and Philosophy and Sufism

- The Heart of Islam: Enduring Values for Humanity

- Islamic Philosophy from its Origin to the Present: Philosophy in the Land of Prophecy

- Poems of the Way

- The Pilgrimage of Life and the Wisdom of Rumi

- Islam: Religion, History, and Civilization

- Islam, Science, Muslims, and Technology: Seyyed Hossein Nasr in Conversation with Muzaffar Iqbal

- The Essential Seyyed Hossein Nasr, edited by William Chittick. ${ }^{6}$

Pada 1961-1962, Nasr menjadi dosen tamu di Centre for the Study of World Religions di Harvard, di mana ia menyampaikan kuliah terbuka tentang Ibn Sina, Surahwardi dan Ibn 'Arabi yang kemudian di terbitkan sebagai buku dengan judul Three Muslim Sages. Buku tersebut telah diterjemahkan ke dalam seluruh bahasa penting umat Islam.

Selama tinggal di Iran (1959-1979), Nasr telah menulis banyak kumpulan buku, artikel dan karya-karya lain. Ia menerbitkan lebih dari dua puluh buku dan ratusan artikel (termasuk kata pengantar dan resensi buku) dalam bahasa Inggris, Persia dan Prancis. Buku-buku yang ditulis pada masa itu dapat dibagi ke alam dua bagian penting. Pertama, buku-buku yang berkaitan dengan Sains Islam, yang meliputi An Introduction to Islam Cosmological Science, Science an Civilization in Islam dan Islamic Science An Illustrate Study. Bagian kedua adalah buku-buku yang berkaitan dengan filsafat perennial, yang meliputi buku-buku tentang Sufisme dan Filsafat Islam, seperti Ideals and Realties of Islam, Man and Nature, Islam and the Plight of Modern Man, Three Muslim Sages dan Sufi Essays.

Nasr berusaha menyadarkan kosmologi dan sains Islam. Ia melihat sains Islam tidak hanya sebagai jembatan antara barang Yunani-Romawi dan Abad Pertengahan di Barat; juga bukan sekadar tangga perkembangan

${ }^{6}$ From Wikipedia, the free encyclopedia, http://en.wikipedia.org/wiki/Hossein_Nasr\#Education 
sejarah Sains Barat, tetapi sebagai jalan alternatif malihat sesuatu. ${ }^{7}$ Buku terpenting dalam bidang ini adalah An Introduction to Islamic Cosmological Doctrine (1964).Buku yang lain dalam bidang ini adalah Science and Civilization in Islam (1968), yang diberi kata pengantar oleh Giorgio Di Santillana. Dalam buku ini Nasr berbicara tentang sistem pengajaran dan lembaga-lembaga Islam tradisional. Ia memberikan penjelasan historis sains dalam budaya Islam, yaitu Kosmologi, Kosmografi, Geografi, Sejarah Alam, Fisika, Matematika, Astronomi, Kedokteran dan Kimia. Berkat studinya tentang sains di M.I.T, Nasr mengembangkan kritik yang konsisten terhadap sains modern. Ia menegaskan bahwa dalam peradaban tradisional, sains merupakan bagian dan bidang alam suci yang ada. Pencerahan secara salah telah memisahkan sains dari agama atau prinsip-prinsip suci, yang menyebabkan munculnya sekularisasi. Karena itu, sains yang di-desakralisasi, dengan memproklamirkan ketakterikatannya dari agama, telah menjadi kekuatan tak terkendali, yang menimbulkan masalah-masalah yang mengancam keberadaan manusia. Nasr juga menentang pengulangan dan peniruan buta terhadap sains modern oleh orang-orang Muslim yang tidak memperhatikan konsekuensi-konsekuensi tindakan tersebut bagi Islam dan kehidupan Muslim.

Tiga buku yang ditulis dari prespektif filsafat perennial juga penting untuk disebut. Yaitu, Man and Nature (1068), Sufi Essays (1972), dan Islam and the Pligh of Modern Man (1975). Pada 1979, situasi politik di Iran memaksa Nasr harus meninggalkan negerinya. Ia hanya membawa sedikit uang dan beberapa kopor dan memulai membangun kembali kehiupannya di Amerika. Antara 1979 dan 1995, Nasr telah menambah daftar terbitannya yang masif lebih dari sepuluh buku dan sejumlah artikel. Di samping karya ilmiahnya yang intensif, ia juga mencurahkan berbagai usaha melakukan terjemahan, baik dari Persia ke Inggris maupun dari Inggris dan Prancis ke Persia dan Arab. Empat buku khusus yang ditulis pada masa ini yaitu Knowledge and the Sacred (1981), Traditional Islam in the Modern World (1987, Islamic Art an Spirituality (1987), dan The Need for Sacred Science (1993) layak untuk mendapatkan penjelasan singkat. Di samping pendidikan tradisional dan klasiknya, dan pengalaman lintas budaya, Nasr juga mengenal dengan baik ilmu-ilmu fisika dan sosial, sejarah dan filsafat Barat, serta ajranajaran dan teologi Kristen klasik dan modern. Seperti dengan tepat dilihat oleh J.I. Smith, identitas Syi'ah Persia Nasr, meskipun nampak jelas dalam beberapa penjelasannya, tidak mewarnai tulisan-tulisannya secara berlebih.

\footnotetext{
${ }^{7}$ Nasr, Quest of the Eternal, h. 117-118.
} 


\section{Usaha Pencarian Autensitas}

Seyyed Hossein Nasr menegaskan bahwa yang terjadi di Dunia Islam tidak seperti yang dibayangkan para pengamat selama ini. Samuel Huntington, misalnya, penulis buku Clash of Civilization, mengatakan bahwa Islam itu ancaman terhadap Barat. Menurut Nasr, anggapan ini tidak sepenuhnya benar karena dalam kenyataannya, sebenarnya ada sekelompok Muslim yang berwawasan 'liberal'. Dan kenyataan ini memang sungguhsungguh ada, dan sedang dalam pertumbuhan di banyak bagian Dunia Islam. Tetapi dibandingkan para pemikir Muslim lainnya, kelebihan Nasr sebagai pemikir Muslim, bahwa ia selalu menunjukkan dengan tegas krisis-krisis dari masyarakat modern, seperti para senior dan kawan seperjuangan, Rene Guenon, Frithjof Schuon, Martin Lings, dan Titus Burkhart. Banyak kalangan Barat berpendapat, tidak mungkin orang Islam itu "liberal". Karena orang Islam dalam pandangan Barat digambarkan secara eksotik. Islam terlalu sering diindentifikasikan sebagai fundamentalis, fanatik, dan penuh dengan kekerasan, kezaliman, dan tidak beradab. Dan pikiran orang Barat yang sempit itu akan terbantahkan jika kita membaca buku Nasr ini, yakni The Heart of Islam, atau juga buku-buku dari pemkir Islam yang kita kenal progresif, dari macam-macam negara Muslim, seperti Asgar Ali Enginer, Fatima Mernisi, Muhammad Arkoun, Fazlur Rahman, atau Nurcholis Madjid.Pertanyaan-pertanyaan mereka juga pertanyaan Nasr adalah: Kalau ada ide-ide dan pemikiran baru di dalam masyarakat, misalnya mengenai paham negara dan demokrasi, apakah Islam bisa mengambil, mengadaptasi, atau menerima paham tersebut? Paham mengenai negara dan demokrasi itu sebenarnya adalah suatu konsep yang baru sama sekali. Baru di zaman modern inilah ada pemikiran mengenai negera dan demokrasi sebagai Modern Nation State. Umumnya kalangan pemikir Muslim kontemporer ini terbuka terhadap ide-ide progresif 'kemajuan', apalagi yang sudah mendapatkan pematangan dalm suatu wacana kemanusiaan.

\section{Isu Global Dewasa Ini}

Kalau kita mengamati tema-tema yang dibahas para pemikir Muslim dewasa ini dalam pencarian mereka untuk autentisitas Islam itu, kira-kira ada enam isu: pertama, penafsiran yang melawan teokrasi (againts theocracy). Kedua, mendukung gagasan demokrasi, yang biasanya dibicarakan dengan cara liberal syariah. Ketiga, tentang hak-hak perempuan, yaitu seputar penafsiran golongan Islam Liberal tentang isu gender atau malah femenisme. 
Keempat, mengenai hak-hak non-Muslim. Kelima, mengenai kebebasan berpikir. Dan keenam, berkaitan dengan gagasan kemajuan, yang hingga saat ini masih problematik walaupun sudah tidak sekontroversi masa lalu.

Seyyed Hossein Nasr, Fazlur Rahman, juga Nurcholis Majid di Indonesia, merupakan contoh yang paling ekspresif ari cenikiawan Muslim yang menolak pemaksaan keseragaman penafsiran. Dia menulis bahwa perbedaan pendapat itu merupakan hal yang penuh arti dan harus dinilai positif. karena itu, kebebasan berpikir dan penerimaan paham kemajuan merupakan hal yang sangat penting untuk kemajuan Islam itu sendiri.dan kalau dalam hal ini terjadi perbedaan pendapat berkaitan dengan penyusaian diri Islam atas kemajuan-kemajuan itu,perbedaan itu merupakan sesuatu yang akan bernilai tinggi, justru untuk memajukan Islam. Karena itu, ia sangat menekankan bahwa paham Islam itu terbuka untuk kemajuan walaupun itu datangnya tidak dari Islam. Enam isu Islam dewasa ini memang tidak memadai untuk menggambarkan keseluruhan isu umat Islam kontemporer. Tetapi kita bisa melihat kompleksitasnya.Da $\mathrm{n}$ keenam isu ini memang banyak dibicarakan dalam pemikiran Islam kontemporer, termasuk di Indonesia walaupun kita tahu sebenarnya ini bukan satu-satunya model untuk melihat pergulatan umat Islam mencari autentisitasnya.

\section{Prestasi dan Karya Nasr}

Seyyed Hossein Nasr merupakan salah satu ilmuwan terkemuka dunia dalam bidang ilmu pengetahuan Islam dan spiritualitas. Ia adalah tokoh intelektual yang sangat dihormati, baik di Barat maupun dunia Islam. Ia juga dikenal luas sebagai pengarang sejumlah buku dan artikel yang laris. Lebih dari 50 buku dan 500 artikel yang ditulisnya telah diterjemahkan ke dalam berbagai bahasa, beberapa di antaranya adalah Man and Nature:

Spiritual Crisis of Modern Man (Kazi Publications, 1998), Religion and The Order of Nature (Oxford, 1996), dan Knowledge and the Sacred (SUNY, 1989). Profesor Studi Islam pada Universitas George Washington, Amerika Serikat, ini menghabiskan sebagian besar hidupnya dengan berkarier sebagai seorang guru. Karier mengajarnya dimulai pada usia belia, 22 tahun, ketika ia mengambil program doktor di Universitas Harvard, Amerika Serikat. Selama bertahun-tahun, dia mengajar siswa dari berbagai belahan dunia. Banyak di antara muridnya yang kini menjadi ilmuwan terkemuka dalam berbagai disiplin ilmu.Selepas menamatkan studi di Universitas Harvard, ia melanjutkan karier mengajarnya di tanah kelahirannya, Iran. Sejak 1958, Nasr mengajar di Universitas Teheran. Lima tahun kemudian pada usia tiga puluh, ia 
diangkat sebagai profesor penuh dalam bidang studi filsafat dan ilmu sejarah di Universitas Teheran. Dan sejak 1968 hingga 1972, ia diangkat menjadi dekan fakultas sekaligus wakil rektor bidang akademik. Dia menggunakan posisi dan pengaruh yang dimilikinya untuk membawa perubahan besar pada lembaga pendidikan tinggi ternama di negeri para mullah ini. Dia berusaha untuk memperkuat dan memperluas program studi filsafat di Universitas Teheran, yang seperti kebanyakan program studi lain sangat didominasi dan dipengaruhi oleh para intelektual Prancis. Selama mengajar di Universitas Teheran, Profesor Nasr mendorong para mahasiswanya untuk belajar filsafat dan tradisi keilmuan lainnya dari sudut pandang mereka sendiri, bukan dari perspektif pemikiran dan filsafat Barat seperti yang diterapkan oleh banyak perguruan tinggi di dunia. Menurutnya, seseorang tidak bisa berharap banyak untuk bisa memahami sesuatu dari sudut pandang orang lain. Hal ini, ungkap dia, ibaratnya sama seperti orang yang berusaha melihat melalui mata orang lain.

\section{Kesadaran Tinggi.}

Dia juga berupaya menciptakan kesadaran dan minat yang lebih besar dalam studi filsafat Timur di kalangan mahasiswa dan dosen Universitas Teheran. Mengingat Universitas Teheran adalah satu-satunya universitas di Iran saat itu yang menawarkan gelar doktor dalam bidang filsafat. Langkah perubahan yang dilakukan Profesor Nasr ini di kemudian hari banyak ditiru oleh universitas-universitas lain di Iran dan memiliki pengaruh kuat di negara tersebut.

Pada 1972, ia ditunjuk sebagai Rektor Universitas Aryamehr oleh penguasa Iran saat itu, Syah Iran. Universitas Aryamehr merupakan sekolah tinggi teknik dan sains terkemuka di Iran. Pemerintah Iran saat itu menginginkan adanya sebuah model universitas seperti Massachusetts Institute of Technology (MIT) di negeri Paman Sam, namun tetap mengedepankan nilai-nilai budaya Iran. Karenanya, Nasr kemudian membuka program studi humaniora dalam bidang kajian budaya Islam dengan penekanan khusus pada filsafat Islam di Universitas Aryahmer.

Langkah Nasr ini menjadikan Universitas Aryamehr sebagai perguruan tinggi pertama di dunia Islam yang memiliki program pascasarjana dalam bidang ilmu filsafat Islam. Pada 1973, Ratu Iran menunjuk Profesor Nasr untuk mendirikan sebuah pusat kajian dan penyebaran filsafat bernama Iran Imperial Academy of Philosophy. Akademi filsafat ini di kemudian hari menjadi salah satu pusat kegiatan pengembangan ilmu filsafat yang paling 
utama di dunia Islam, perpustakaan filsafat terbaik di Iran serta menjadi rujukan bagi para sarjana filsafat, baik dari dunia Timur maupun Barat. Para sarjana ini datang jauh-jauh untuk belajar karena pihak akademi kerap menyelenggarakan seminar dan kuliah yang diberikan langsung oleh para filosof. Selain pihak akademi juga menawarkan program beasiswa jangka pendek dan panjang untuk penelitian di bidang filsafat Islam, perbandingan filsafat, dan program bahasa seperti bahasa Persia, Arab, Inggris, dan Prancis. Pada 1961-1962, Nasr menjadi dosen tamu di Centre for the Study of World Religions di Harvard, di mana ia menyampaikan kuliah terbuka tentang Ibn Sina, Surahwardi dan Ibn 'Arabi yang kemudian di terbitkan sebagai buku dengan judul Three Muslim Sages. Buku tersebut telah diterjemahkan ke dalam seluruh bahasa penting umat Islam.

Selama tinggal di Iran (1959-1979), Nasr telah menulis banyak kumpulan buku, artikel dan karya-karya lain. Ia menerbitkan lebih dari dua puluh buku dan ratusan artikel (termasuk kata pengantar dan resensi buku) dalam bahasa Inggris, Persia dan Prancis. Buku-buku yang ditulis pada masa itu dapat dibagi ke alam dua bagian penting. Pertama, buku-buku yang berkaitan dengan Sains Islam, yang meliputi An Introduction to Islam Cosmological Science, Science an Civilization in Islam dan Islamic Science An Illustrate Study. Bagian kedua adalah buku-buku yang berkaitan dengan filsafat perennial, yang meliputi buku-buku tentang Sufisme dan Filsafat Islam, seperti Ideals and Realties of Islam, Man and Nature, Islam and the Plight of Modern Man, Three Muslim Sages dan Sufi Essays. ${ }^{8}$ Nasr berusaha menyadarkan kosmologi dan sains Islam. Ia melihat sains Islam tidak hanya sebagai jembatan antara barang Yunani-Romawi dan Abad Pertengahan di Barat; juga bukan sekadar tangga perkembangan sejarah Sains Barat, tetapi sebagai jalan alternatif malihat sesuatu. Buku terpenting dalam bidang ini adalah An Introduction to Islamic Cosmological Doctrine (1964). ${ }^{9}$

Buku yang lain dalam bidang ini adalah Science and Civilization in Islam (1968), yang diberi kata pengantar oleh Giorgio Di Santillana. Dalam buku ini Nasr berbicara tentang sistem pengajaran dan lembaga-lembaga

\footnotetext{
${ }^{8}$ Nasr dalam karyanya ini berhasil mempertemukan Filsafat, sains dan intuisi sufistik yang esoterik, menggabungkan ketiganya akan menjembatani akal dengan hati, filsafat dengan qalb, rasio dan spirit.

9 Banyak peneliti sejarah menyatakan bahwa Yunani dan Romawi mempunyai perbedaan yang sangat fundamental, Bangsa Yunani mempunyai watak pemikir dan filsafat dan tidak suka berperang, sedang Romawi gemar berperang dan tidak suka memikirkan yang rumit-rumit dan mempunyai jiwa arsitektur yang tinggi. Menurut Nasr di sinilah perjumpaan Yunani dan Romawi sama-sama menyincintai seni, jika Yunani gemar dengan seni lukis sedang Romawi suka sini ukir dan arsitektur dan seni berperang.
} 
Islam tradisional. Ia memberikan penjelasan historis sains dalam budaya Islam, yaitu Kosmologi, Kosmografi, Geografi, Sejarah Alam, Fisika, Matematika, Astronomi, Kedokteran dan Kimia. Berkat studinya tentang sains di M.I.T, Nasr mengembangkan kritik yang konsisten terhadap sains modern. Ia menegaskan bahwa dalam peradaban tradisional, sains merupakan bagian dan bidang alam suci yang ada. Pencerahan secara salah telah memisahkan sains dari agama atau prinsip-prinsip suci, yang menyebabkan munculnya sekularisasi. Karena itu, sains yang di-desakralisasi, dengan memproklamirkan ketakterikatannya dari agama, telah menjadi kekuatan tak terkendali, yang menimbulkan masalah-masalah yang mengancam keberadaan manusia. Nasr juga menentang pengulangan dan peniruan buta terhadap sains modern oleh orang-orang Muslim yang tidak memperhatikan konsekuensi-konsekuensi tindakan tersebut bagi Islam dan kehidupan Muslim.

Tiga buku yang ditulis dari prespektif filsafat perennial juga penting untuk disebut. Yaitu, Man and Nature (1068), Sufi Essays (1972), dan Islam and the Pligh of Modern Man (1975). Pada 1979, situasi politik di Iran memaksa Nasr harus meninggalkan negerinya. Ia hanya membawa sedikit uang dan beberapa kopor dan memulai membangun kembali kehidupannya di Amerika.

Antara 1979 dan 1995, Nasr telah menambah daftar terbitannya yang masih lebih dari sepuluh buku dan sejumlah artikel. Di samping karya ilmiahnya yang intensif, ia juga mencurahkan berbagai usaha melakukan terjemahan, baik dari Persia ke Inggris maupun dari Inggris dan Prancis ke Persia dan Arab.

Empat buku khusus yang ditulis pada masa ini yaitu Knowledge and the Sacred (1981), Traditional Islam in the Modern World (1987, Islamic Art an Spirituality (1987), dan The Need for Sacred Science (1993) layak untuk mendapatkan penjelasan singkat.

Di samping pendidikan tradisional dan klasiknya, dan pengalaman lintas budaya, Nasr juga mengenal dengan baik ilmu-ilmu fisika dan sosial, sejarah dan filsafat Barat, serta ajran-ajaran dan teologi Kristen klasik dan modern. Seperti dengan tepat dilihat oleh J.I. Smith, identitas Syi'ah Persia Nasr, meskipun nampak jelas dalam beberapa penjelasannya, tidak mewarnai tulisan-tulisannya secara berlebih. 


\section{Usaha Pencarian Autensitas}

Seyyed Hossein Nasr menegaskan bahwa yang terjadi di Dunia Islam tidak seperti yang dibayangkan para pengamat Islam selama ini. Samuel Huntington, misalnya, penulis buku Clash of Civilization, mengatakan bahwa Islam itu ancaman terhadap Barat. Menurut Nasr, anggapan ini tidak sepenuhnya benar karena dalam kenyataannya, sebenarnya ada sekelompok Muslim yang berwawasan 'liberal'. Dan kenyataan ini memang sungguhsungguh ada, dan sedang dalam pertumbuhan di banyak bagian Dunia Islam. Tetapi dibandingkan para pemikir Muslim lainnya, kelebihan Nasr sebagai pemikir Muslim, bahwa ia selalu menunjukkan dengan tegas krisis-krisis dari masyarakat modern, seperti para senior dan kawan seperjuangan, Rene Guenon, Frithjof Schuon, Martin Lings, dan Titus Burkhart.

Banyak kalangan Barat berpendapat, tidak mungkin orang Islam itu "liberal". Karena orang Islam dalam pandangan Barat digambarkan secara eksotik. Islam terlalu sering diindentifikasikan sebagai fundamentalis, fanatik, dan penuh dengan kekerasan, kezaliman, dan tidak beradab. Dan pikiran orang Barat yang sempit itu akan terbantahkan jika kita membaca buku Nasr ini, yakni The Heart of Islam, atau juga buku-buku dari pemkir Islam yang kita kenal progresif, dari macam-macam negara Muslim, seperti Asgar Ali Enginer, Fatima Mernisi, Muhammad Arkoun, Fazlur Rahman, atau Nurcholis Madjid. Pertanyaan-pertanyaan mereka juga pertanyaan Nasr adalah: Kalau ada ide-ide dan pemikiran baru di dalam masyarakat, misalnya mengenai paham negara dan demokrasi, apakah Islam bisa mengambil, mengadaptasi, atau menerima paham tersebut? Paham mengenai negara dan demokrasi itu sebenarnya adalah suatu konsep yang baru sama sekali. Baru di zaman modern inilah ada pemikiran mengenai negara dan demokrasi sebagai Modern Nation State. Umumnya kalangan pemikir Muslim kontemporer ini terbuka terhadap ide-ide progresif 'kemajuan', apalagi yang sudah mendapatkan pematangan dalam suatu wacana kemanusiaan.

\section{Filsafat dan Pemikirannya}

John F. Haugh ; dalam bukunya: Science and Religion: From

Conflict to Conversation. Mengajukan suatu pertanyaan yang sangat menggelitik, apakah agama bertentangan dengan sains?, untuk menjawab pertanyaan itu Haught menjawab dengan empat pendekatan, yaitu pendekatan konflik, pendekatan kontras, pendekatan kontak dan pendekatan 
konfirmasi. ${ }^{10}$ Apa yang menjadi pemikiran John $\mathrm{F}$ Haugh adalah bahwa harus ada dialog antara sains dan agama, karena berbeda dengan dunia Islam yang menselaraskan agama dengan sains sementara Barat justru meyakini kebenaran ganda bahwa bahasa agama tidak bisa dipahami dengan bahasa sains, bahasa agama hanya bisa dipahami dengan bahasa agama, dan dengan instrument agama misalnya semecam pendekatan hermeuneutic ${ }^{11}$, dan atau penafsiran-penafsiran lain. Sementara sains untuk mengujinya harus dengan riset yang sistematis dilaboratorium, semakin diteliti akan semakin diketahui titik lemahnya dan atau malah kelebihannya.

Seyyed Hossein Nasr memberikan jawaban perjumpaan sains dan agama dengan suatu pendekatan filisofis sebagaimana ia kemukakan : Religions Perennis atau Philosophy Perennis yang dalam istilah Indonesia lebih popular dengan Agama dan Filsafat Perennial. Apa yang menjadi inti dari pemikiran agama dan filsafat perennial itu, adalah bahwa ada sesuatu yang abadi dalam agama itu, yang dengan keabadiannya menjadi kajian filosofis dan dengan keabadiannya menjadi kajian sistematis dan ilmiah: Ajaran filsafat yang dikenal baik sebagai masysya'i atau filsafat paripatik adalah sintetis ajaran-ajaran wahyu Islam, Aristotelianiseme dan neoplatonisme, baik Atenian maupun Alexsandrian, ditemukan pada abad III/IX dalam iklim intelektual yang kaya di Bagdad oleh Abu Ya'qub al-Kindi (w. 260/873). Ia juga disebut filosof berkebangsaan Arab yang banyak karyakaryanya, dan telah menyusun lebih dari dua ratus penjelasan secara rinci, dalam kaitannya dengan sains dan filsafat, mulai sebuah kecenderungan yang mencirikan kelompok Muslim bijaksana, yakni filosof saintis dan tidak hanya filosof-filosof. ${ }^{12}$ Inti dari filsafat ini adalah menemukan kebenaran dimana pun ia ada. Menurut Nasr kebenaran ini disebut kebenaran abadi apabila ia bisa dijumpai dalam agama maupun filsafat, sehingga ia disebut

10 John F. Haugh, Science and Religion: From Conflict to Conversation, Paulist Press, New York, 1995. diterjemahkan ke dalam bahasa Indonesia dengan Judul; Perjumpaan sains dan Agama, Mizan, Bandung, 2004. h. 1-2.

${ }^{11}$ Richard E. Palmer, menjelaskan bahwa Hermeuneutika merupakan senjata paling jitu ketika ingin memahami bahasa agama secara tematik, bahwa ketika ingin menjelaskan suatu tema maka segala sesuatu yang berkaitan dengan tema itu harus digunakan, dengan demikian maka segala sesuatu yang berkaitan dengan tema itu bahwa akan menjadi jelas dengan sendirinya. Lihat, Hermeneutika; Teori Baru Mengenai Interpretasi, Pustaka Pelajar, Yogyakarta, 2003. h. 14-15.

12 Seyyed Hossein Nasr, Qutb al-Din Syirazi, dalam Dictionary of Saintifik Biography, Ed. C. Gillespie (New York: Charles Scribner's Sons, 1976). Hal. 53-247. Dapat juga anda jumpai dalam; Alija Ali Izet Begovic, seorang Filosuf asal Bosnia Herzegovina, dalam bukunya; Islam Between East and West, American Trust Publication, 1984. Dan buku ini telah diterjemahkan ke dalam bahasa Indonesia dengan judul: Membangun Jalan Tengah, Islam antara Timur dan Barat, Mizan, Bandung, 1992. Hal. 281-284. 
sebagai agama abadi atau filsafat abadi (religion Perennis atau Philosophy Perennis). Agama merupakan pengakuan manusia untuk bersikap pasrah kepada sesuatu yang lebih tinggi, lebih agung dan lebih kuat dari mereka, yang bersifat transedental. ${ }^{13}$ Telah menjadi fitrah manusia untuk memuja dan sikap pasrah kepada sesuatu yang dia agung-agungkan untuk dijadikan sebagai Tuhannya. ${ }^{14}$ Sering kali kita membaca dua sejarah besar antar Islam dan Barat seakan-akan tak pernah saling bertemu antara keduanya atau seperti dua sejarah yang harus dibedakan antara keduanya. Padahal tidaklah begitu, ketika kita mau membaca atau menyimak sejarah, sains dan ilmu pengetahuan yang kini telah berkembang pesat di era millenium sekarang ini. Justru terilhami dari kebangkitan sains Islam pada abad renaissance Islam pada masya Dinasty Abbasiyah.

Secara filosofis bisa dilihat ketika dunia Islam dalam keemasan, banyak orang-orang Eropa (Barat) pada umumnya, sekitar kurang lebih abad pertengahan, negara-negara Barat mengalami kegelapan dan kemunduran, setelah berapa saat mengalami kemajuan dibidang filsafat-khususnya di negara Yunani-diawal abad Masehi. Alam pikir mereka cenderung mengarah pada profanistik. Sehingga Barat harus mengakui kemundurannya. Kemajuan yang terjadi didunia Islam, ternyata memiliki daya tarik tersendiri bagi mereka orang-orang Barat. Maka pada masa seperti inilah banyak orangorang Barat yang datang ke dunia Islam untuk mempelajari filsafat dan ilmu pengetahuan. Kemudian hal ini menjadi jembatan informasi antara Barat dan Islam. Dari pemikiran-pemikiran ilmiah, rasional dan filosofis, atau bahkan sains Islam mulai ditransfer ke-daratan Eropa. Kontak antara dunia Barat dan Islam pada lima Abad berikutnya ternyata mampu mengantarkan Eropa pada masa kembangkitannya kembali (renaisance) pada bidang ilmu pengetahuan dan filsafat. Selanjutnya berkembang pada era baru yaitu era-modern.

Zaman baru di Barat yang kemudian lazim dikenal sebagai abad Modern dimulai kurang lebih abad ke-17. Merupkan awal kemenangan supermasi rasionalisme, empirisme, dan positifisme dari dogmatis Agama. Kenyataan ini dapat dipahami karena abad modern Barat ditandai dengan adanya upaya pemisahan antara ilmu pengetahuan dan filsafat dari pengaruh Agama (sekulerisme). Perpaduan antara rasionalisme, empirisme dan positifisme dalam satu paket epistimologi melahirkan apa yang T.H Huaxley

13 Pengertian Islam secara Generik, adalah sikap pasrah dan tunduk kepada kehendak Tuhan, Nurcholish Madjid juga menyatakan hal sama sebagai mana dalam bukunya: Islam Kemodernan dan Keindonesiaan, Mizan, Bandung, cet. Iv. h. 47.

14 ibid. 
disebut dengan Metode Ilmiah (Scientific Method). ${ }^{15}$ Munculnya aliran-alran tersebut sangat berpengaruh pada peradaban Barat selanjutnya. Dengan meode ilmiah itu, kebenaran sesuatu hanya mereka perhitungkan dari sudut fisiologis-lahiriah yang sangat bersifat profanik (keduniawian atau kebendaan). Atau dengan istilah lain, kebenaran ilmu pengetahuan hanya diukur dari sudut koherensi dan korespodernsi. Dengan wataknya tersebut sudah dapat dipastikan bahwa, segala pengetahuan yang berada diluar jangkauan indra dan rasio serta pengujian ilmiah ditolaknya, termasuk didalamnya penegtahuan yang bersumber pada Religie. Dengan demikian, Zaman Modern atau Abad Modern di Barat adalah zaman, ketika manusia menemukan dirinya sebagai kekuatan yang dapat menyelesaikan segala persoalan-persoalan hidupnya. Manusia hanya dipandang sebagai mahluk yang bebas yang independen dari Alam dan Tuhan. Manusia di Barat sengaja membebaskan dari Tatanan Ilahiah (Theo Morphisme), untuk selanjutnya membangun Tatanan Antropomorphisme suatu tatanan yang semata-mata berpusat pada manusia. Manusia menjadi tuan atas nasibnya sendiri. Hingga kemudian mulai bermunculan gerakan-gerkan responsif alternatif sebagai respon balik terhadap prilaku masyarakat modern yang tidak lagi mengenal dunia metafisik. Termasuk didalamnya Tradisonalisme Islam yang dihidupkan Nasr, atau gerakan New Age di Barat pada akhir dewasa ini.

\section{Pandangan Said Hossein Nasr Terhadap Barat.}

Dengan Kontek ini, perlu juga ditegaskan antar hubungan Barat yang modern dan peran Agama resmi yang berlaku disana, yakni kristen. Ada sebagian orang beranggapan bahwa seluruh orang Barat menganut Agama Kristen, dengan perkecualian minoritas penganut Yahudi. Anggapan semacam ini seolah-olah Barat masih seperti Barat pada abad pertengahan, ketika terjadi perang salib yang perabannya saat itu adalah disebut abad keimanan. Ada juga sebagian yang lain beranggapan sebaliknya, yaitu bahwa seluruh orang Barat bersifat materialisk atau agnostik serta skeptik dan tidak menganut satu Agama apapun. Pandangan semacam ini bisa disebut keliru, karena yang terjadi tidaklah demikian. Pada Abad ke-17, bahkan sebelumnya, yaitu ketika renaisans, telah terjadi upaya membawa dunia Baat kearah sekularisme dan penipisan peran Agama dalam kehidupan sehari-hari manusia. Akhirnya berakibat pada sejumlah orang Barat yang secara praktis tidak lagi menganut Agama Kristen atau Yahudi. Orang semacam Comte, yang pikiran-pikirannya begitu anti metafisis menjadi jalan mulus menuju

\footnotetext{
15 Seyyed Hossein Nasr, of.cit.
} 
kearah sekularisme Dunia Barat. Ditambah dengan ajaran filsafat sosial (sosialisme), Marx (Maxisme) yang menegaskan bahwa Agama adalah candu masyarakat, yang karenanya ia harus ditinggalkan. Puncak penolakan terhadap Agama Kristen di Barat disuarakan oleh Nietzsche dengan statemennya yang banyak di kenal orang The God is dead.

Kemunculan gagasan-gagasan semacam itu mungkindiakibatkan adanya ketidak mampuan sistem keimanan sistem yang berlaku disana untuk mengakomodasikan perkembangan masyarakat modern dengan ilmu pengetahuanya. Kermajuan masyarakat yang sudah berhasil dan begitu percaya pada iptek, akhirnya berkembang lepas dari kontrol Agama. Iptek yang landasan pokoknya bersifat sekuler bagi sebagian besar orang di Barat akhirnya menggantikan posisi Agama. Segala kebutuhan Agama seolah bisa terpenuhi dengan iptek. Namun dalam kurung waktu yang panjang iptek ternyata menghianati kepercayaan manusia, kemajuan iptek justru identik dengan bencana. Kondisi inilah yang tampaknya membuat masyarakat Barat mengalami apa yang disebut Cak Nur (Dr. Nurkholis Madjid) yang dikutipnya dari Baigent, Krisis Epistimologis, Yakni masyarakat Barat tidak lagi menegtahui tentang makna dan tujuan hidup (Meaning and Purpose of Life). ${ }^{16}$

Manusia modern semakin memperparah dirinya dengan yang dia nyatakan sendiri; karena ia telah lupa sipakah ia sesungguhnya. Seperti yang dilakukan Faust setelah menjual jiwanya untuk memperoleh kekuasaan terhadapa lingkungan alam manusia ia menciptakan suatu situasi, dimana kontrol terhadap lingkungan berubah menjadi pencekikan, yang selanjutnya tidak hanya berubah menjadi kehancuran ekonomi, tetpi juga perbuatan bunuh diri. Begitulah dunia belakangnan ini juga ditandai pembicaraan tentang krisis lingkungan hidup. Dimulai dengan laporan mengenai batasbatas pertumbuhan sekitar 25-an tahun lalu, hingga konfernsi bumi (Earth Summith) di Rio De Janeiro tahun lalu. Manusia dewasa ini semakin sadar bahwa seluruh krisis dibumi ini, tidak hanya disebabkan karena alasan material-dulu sering diungkap oleh banyak ahli-tapi justru lebih pada sebabsebab yang bersifat transedental: sebab-sebab cara pandang manusia terhadap alam ini. Dunia modern sekarang ini, tidak lagi memiliki 'horizon spiritual'. Ini bukan berarti horizon spiritual itu tidak ada, tapi karena manusia modern-dalam istilah Filsafat Perrenial-hidup dipinggir lingkaran eksistensi.

${ }^{16}$ Dilema manusia modern adalah ketika kehilangan pegangan, kehilangan makna dan tujuan hidup, ketika spirit agama digantikan oleh upacara dan seremonial belaka, maka yang terjadi adalah kegersangan spiritual. 
Manusia modern melihat segala sesuatu hanya dari pinggiran eksistensinya saja, tidak pada pusat spiritualitas dirinya, sehingga mengakibatkan ia lupa siapa dirinya. Memang dengan apa yang dilakukannya sekarang-memberi perhatian pada dirinya yang secara kuantitatif sangat mengangumkan, tapi secara kualitatif dan keseluruhan tujuan hidupnya-menyangkut pengertianpengertian mengenai dirinya sendiri-ternyata dangkal. Dekadensi atau kejatuhan manusia di zaman modern ini terjadi karena mansuia kehilangan 'pengetahuan langsung' mengenai dirinya itu, dan menjadi bergantung berhubungan dengan dirinya. Itu sebabnya, dunia ini menurut pandangan manusia adalah dunia yang memang tak memiliki dimensi transedental. Dengan demikian menjadi wajar jika peradaban modern yang dibangun selama ini tidak menyertakan hal ayng paling esensial dalam kehidupan manusia, yaitu dimensi spiritual. Belakangan ini baru disadari adanya krisis spiritual dan krisis pengenalan diri.

Sejarah pemikiran Barat modern, sejak Rene Descartes ditandai dengan usaha menjawab tantangan keberadaan manusia sebagai mahluk mikro kosmik. Dengan falsafahnya yang amat terkenal cogito ergo sum (karena berpikir maka aku ada). Tetapi sayangnya, bukan pengertian yang makin mendalam yang didapat, namun justru keadaan yang semakin menjauh dari eksistensi dan pengertian yang tepat mengenai hakekat diri yang diperoleh. Max Scheeler, Filsafat Jerman dari awal abad ini mengatakan, tak ada periode lain dalam pengetahuan bagi dirinya sendiri, seperti pada periode kita ini. Kita katanya-punya antropologi ilmiah, antropologi filosofis, dan antropologis teologis yang tak saling mengenal satu sama lain. Tapi kita tidak memiliki gambaran yang jelas dan konsisten tentang keberadaan manusia (human being). Semakin bertumbuh dan banyaknya ilmu-ilmu khusus yang terjun konsepsi kita tentang manusia, malah sebaliknya semakin membingungkan dan mengaburkannya. Maka dari itulah, jika kita kembalikan pada bahasan semula tentang metode ilmiah yang berwatak rasional dan empiris, telah menghantarkan kehidupan manusia pada suasana modernisme. Kemudian pada perkembangan selanjutnya, modernisme melahirkan corak pemikiran yang mengarah pada rasioanalisme, positifisme, pragmatisme, sekulerisme dan materialisme. Aliran-aliran filsafat ini, dengan watak dasarnya yang sekuleris-meminjam istilahnya Fritchjof Schuon-sudah terlepas dari Scintivica Sacra (Pengetahuan suci) atau Philosophia Perenneis (Filsafat Keabadian) Proses modernisasi yang dijalankan Barat yang diikuti negaranegara lain, ternyata tidak selalu berhasil memenuhi janjinya mengangkat harkat kemanusiaan dan sekaligus memberi makna yang lebih dalam bagi 
kehidupan. ${ }^{17}$ Modernisme justru telah diraskan membawa dampak terhadap terjadinya kerancauan dan penyimpangan nilai-nilai. Manusia modern kian dihinggapi rasa cemas dan ketidakberimanan dalam kehidupannya. Mereka telah kehilangan visi keillahiahan atau dimensi ransedental, karena itu mudah dihinggapi kahampaan spiritual. Sebagai akibatnya, manusia modern menderita keterasingan (alienasi), baikteralienasi dari dirinya sendiri, dari lingkungan sosilanya maupun teralienasi dari Tuhannya.

Menyadari kondisi masyrakat modern yang sedemikian, pada abad ke20, terutama sejak beberapa dekade terakhir ini, muncul suatu gerakan yang mencoba menggugat dan mengkritik teori-teori modernisasi, Manusia membutuhkan pola pemikiran baru yang diharapkan membawa kesadaran dan pola kehidupan baru. Kritik terhadap modernisme dan usaha pencarian ini sering disebut dengan masa pasca modernisme (post-modernisme). Masa ini seperti yang dikatakan Jurgen Habermes seorang Sosiolog dan Filosof Jerman tidak hanya ditandai dengan kehidupan yang semakin materialistik dan hedonistik, tetapi juga telah mengakibatkan terjadinya intrusi massif dan krisis yang mendalam pada berbagai aspek kehidupan. Masyarakat pada Era Post-Modernisme mencoba untuk keluar dari lingkaran krisis tersebut dengan kembali pada hikmah spiritual yang terdapat dalam semua Agama otentik. Manusia perlu untuk memikirkan kembali hubungan antara Yang Suci (Sacred) dan yang sekuler (Profan). Gerakan ini dikenal dengan sebutan perenneialisme atau tradisionalisme: adalah sebuah gerakan yang ingin mengembalikan bibit Yang Asali, Cahaya Yang Asali, ataupun prinsip-prinsip yang asali, yang sekarang hilang dari tradisi pemikiran manusia modern. Untuk menyebut beberapa nama tokoh yang memelopori gerakan-gerakan tersebut antara lain; Louis Massignon (m.1962), Rene Guenon, Ananda K. Coomaraswamy, Titus Burckhart, Henry Corbin (m.1978), Martin Lings, Fritcjof Schoun, dan masih banyak lagi. Sementara di kalangan modernis Islam gerakan Pembaharuan dan pemikiran dalam Islam sejak fase 60-an hingga dewa ini mencoba bersikap lebih kritis terhadap ide-ide modernisasi sebelumnya, dan bahkan terhadap sebagian kelompok pemikir Islam yang mencoba mencari alternatif non-Barat. Kelompok yang disebut terkahir misalnya Hasan Albana (m.1949), Abul A'al al-Maududi (m.1979), Sayyid

17 Bahkan modernisasi dianggab telah menimbulkan dehumanisasi yaitu menyebabkan hilangnya sifat kemanusiaan dari manusia. Namun menurut Nasr walaupun modernisasi dianggab gagal menaikkan derjat kemanusiaan bukan berarti kita meninggalkan sains yang merupakan anak kandung dari modernisasi, namun bagaimana mengisi modernisai dengan nilai-nilai spiritual, nilai-nilai philosophy perennis yaitu nilai-nilai kebijakan universal. 
Quthub (m.1965), dan pemuka-pemuka Al-Ikhwan (sering disebut kelompok fundamentalis, atau lebih tepat 'Neo-Revivalis Islam') menghendaki agar semua persoalan kemoderenan selalu dikembalikan kepada acuan al-Qur'an, as-Sunnah dan kehidupan para Sahabat dalam pengertian tekstual. Fazlur Rahman (m.1989), Muhammad Arkoun (l.1928), dan isma'il Raji al-Faruqi (m.1986)-yang sering disebut kelompok Neo-Modernis-berusaha mencarai relevansi Islam bagi dunia modern Islam, bagi mereka, adalah al-Qur'an dan as-Sunnah yang meski ditangkap pesan-pesan tersebut. Kelompok ini dalam pembaharuannya berkecndrungan ke arah humanistik, rasionalistik, dan liberalistik. Sedang tokoh-tokoh muslim lain seperti Ali Syari'ati (m.1979), Hassan Hannafi $(\mathrm{I}, 1935)$, dan Abdillah Larraui (sering disebut penyebar paham Kiri Islam) berkepentingan membela massa, rakyat tertindas dan menampilkan Islam sebagai kekuatan revolusioner-politik. Oleh karenanya kelompok terkhir ini, sering juga disebut sebagai penyebar sosialisme Islam dan Marxisme Islam sebagai model pembangunan di dunia Islam. Mereka mengutuk westernisasi dan sekulerisasi masyarakat Islam, Nasionalisme, dan ekses-ekses kapitalisme, demikian juga materialisme serta ke-tak Bertuhanan Marxisme.

Kemudian selnjutnya lahir tokoh-tokoh pemikir kontemporer lain sebagai pemikir alternatif, yakni Sayyed Hussein Nasr yang mencoba menawarkan konsep nilai-nilai ke-islaman yang kemudian terkenal dengan sebutan 'Tradisionalisme Islam'. Merupakan gerakan respon terhadap kekacauan Barat modern yang sedang mengalami kebobrokan spiritual, dimana menurut penilaian Nasr menyarankan agar Timur menjadi Barat sebagai case study guna mengambil hikmah dan pelajaran sehingga Timur tidak mengulangi kesalahan-kesalahan Barat.Sayyed Hussein Nasr beranggapan, sejauh ini gerakan-gerakan fundamentalis atau revivalis Islam tak lebih merupakan dikotomi tradisionalisme-modernisme, keberadaannya justru menjadi terlalu radikal dan terlalu mengarah kepada misi politis dari pada normatik-religius (nilai-nilai ke-Agamaan). ${ }^{18}$ Sekalipun gerakan-gerakan seperti itu, atas nama pembaharuan-pembaharuan trdisional Islam. Pada momen sejarah ini pulalah saat yang tepat untuk membedakan gerakan-

${ }^{18}$ Dikotomi tradisionalisme Islam dan modernisme telah melahirkan gerakan revivalis di satu sisi dan gerakan spiritualis di sisi lain. Ciri-ciri gerakan revivalis adalah kerinduan terhadap kekuasaan Islam, sebagai kekuatan politik anti terhadap hegemoni Barat dan segala sesuatu yang berasal dari Barat yang dianggap sebagai kekuatan setan inverialisme. Sedangkan gerakan spiritualis adalah gerakan esoteris yang melihat Islam sebagai penyatu kemanusiaan Universal, manusia sebagai satu saudara yang tinggal dalam rumah besar yang bernama alam semesta. 
gerakan yang disebut sebagai 'Fundamentalisme Islam' dari Islam Tradisional yang sering dikelirukan siapapun yang telah membaca karya-karya yang bercorak tradisional tentang Islam dan membandingkannya dengan perjuangan lairan-aliran 'fundamentalis' tersebut segera dapat melihat perbedaan-perbedaan mendasar diantara mereka, tidak saja didalam kandungan tetapi juga didalam 'iklim' yang mereka nafaskan. Malahan yang dijuluki sebagai fundamentalisme mencakup satu spektrum yang luas, yang bagian-bagiannya dekat sekali dengan Interpretasi tradisional tentang Islam. Tetapi tekanan utama macam gerakan polito-religius yang sekarang ini disebut fundamentalisme itu mempunyai perbedaan yang mendasar dengan Islam Tradisional. Dengan demikian perbedaan yang tajam antara keduanya terjustifikasi, sekalipun terdapat wlayah-wilayah tertentu, dimana beberapa jenis fundamentalisme dan dimensi-dimensi khusus Islam Tardisonal bersesuaian. Gerakan TradisonalismeIslam yang diidekan dan dikembangkan Nasr, merupakan gerakan untuk mengajak kembali ke 'akar tradisi'; yang merupakan Kebenaran dan Sumber Asal segala sesuatu; dengan mencoba menghubungkan anatar sekuler (Barat) dengan dimensi ke-Ilahiahan yang bersumber pada wahyu Agama. Tradisionalisme Islam adalah gambaran awal sebuah konsepsi pemikiran dalam sebuah bentuk Sophia Perenneis (keabadian). Tradisonalisme Islam boleh dikatakan juga disebut sebagai gerakan intelektual secara universal untuk mampu merespons arus pemikiran Barat modern (merupakan efek dari filsafat modern) yang cenderung bersifat profanik, dan selanjutnya untuk sekaligus dapat membedakan gerakan Tradisionalisme Islam tersebut dengan gerakan Fundamntalisme Islam, seperti halnya yang dilakukan di Iran, Turki dan kelompok-kelompok fundamentalis lain.

Usaha Nasr untuk menelorkan ide semacam itu paling tidak merupakan tawaran alternatif sebuah nilai-nilai hidup bagi manusia modern maupun sebuah negara yang telah terjangkit pola pikir modern (yang cenderung bersifat profanik dengan gaya sekuleristiknya) untuk kemudian kembali pada sebuah akar tradisi yang bersifat transedental. ${ }^{19}$ Sebagimana

${ }_{19}$ Gagasan Nasr yang mencoba meramu pemikiran Barat yang sekular dengan Tradisi Islam yang bertolak dari Religion Perennis mengindikasikan bahwa menurut Nasr sebenarnya tak ada yang baru, yang ada adalah pengulangan masa lalu dengan suatu ungkapan kekkinian dengan bahasa yang sesuai denga $\mathrm{n}$ tema kekinian. Ketika seorang ilmnuan menemjukan konsep baru yang ada adalah penemuan konsep yang selama ini belum ditemukan yang sebenarnya sudah ada namun belum ditemukan. Itulah sebabnya ketika ada pendapat yang menyatakan bahwa Islam akan bangkit, Nasr menyatakan bahwa kebangkitan Islam itu hanya suatu istilah bahwa tak ada yang istimwa dari pernyataan ini, karena apa yang bangkit adalah sesuatu yang pernah ada. 
yang dipergunakan oleh para kelompok Traditonalis tema tradisi menyiratkan sesuatu Yang Sakral, Yang Suci, dan Yang Absolut. Seperti disampaikan manusia melalui wahyu maupun pengungkapan dan pengembangan peran sakral itu di dalam sejarah kemanusiaan tertentu untuk mana ia maksudkan, dalam satu cara yang mengimplikasikan baik kesinambungan horizontal dengan sumber maupun mata rantai vertikal yang menghubungkan setiap denyut kehidupan tradisi yang sedang diperbincanngkan dengan realitas transeden meta-historikal. Sekaligus makna absolut memiliki kaitan emanasi dan nominasi dari sesuatu sesuatu yang profan dan aksidental. Tradisi menyiratkan kebenaran yang kudus, yang langgeng, yang tetap, kebijaksanaan yang abadi (sophia perenneis), serta penerapan bersinambungan prinsip-prinsipnya yang lansung perennei terhadap berbagai situasi ruang dan waktu. Untuk itulah Islam Tradisional mempertahankan syariah sebagai hukum Ilahi sebagiamana ia dipahami dan diartikan selama berabad-abad dan sebagaimana ia dikristalkan dalam madzab-madzab klasik. Hukum menyangkut kefustifikan, Islam Tradisional memempertahankan Islamitas seni Islam, kaitannya dengan dimensi batini, wahyu Islam dan kristalisasi khazanah spiritual Agama dalam bentuk-bentuk yang tampak dan terdengar, dan dalam domain politik, Perspektif tadisional selalu berpegang pada realisme yang didasarkan pada norma-norma Islam.

\section{KEPUSTAKAAN}

Seyyed Hossein Nasr, The Heart of Islam, terj. Nurasiah Faqih Sutan Harahap Amin Abdullah, Metode Filsafat dalam Tinjauan IImu Agama, (Makalah untuk Simposium Nasional Metodologi Penelitian Filsafat, Yogyakarta: 2729Juni 1991).

Munawar Ahmed Anees dan Merryl W. D., "Sains Islam: Pemikiran Mutakhir danBerbagai Kecenderungan Masa Depan", diterjemahkan oleh Hizbullah Mawlana, dalam Jurnal Al-Hikmah, No. 15, Vol. VI / 1995.Nurul Fajri M. R., "Keterbatasan Perspektif Tradisional: Antara I/mu Normatif atauEmpirisisme", dalam Jurnal Kebudayaan Ulumul Qur'an, No. 4., Vol. III,1992.

Seyyed Hossein Nasr, "Philosophia Perennis and Study of Religion", dalam Frank Whalling, (ed),

The World's Religious Traditions, Current Perspectives in Religious Studies, (Edinburgh: T. \& T. Clark LTD., 1984). 
Seyyed Hossein Nasr, "Existence (wujud) and Quiddity (mahiyyah) in IslamicPhilosophy", dalam Jurnal International Philosophical Quarterly, Vol. XXIX, No. 4., Issue No. 116, December 1989.

Seyyed Hossein Nasr, "In Quest of the Eternal Sophia", (The George WashingtonUniversity, 1990). Seyyed Hossein Nasr, Science and Civilization in Islam, (New York: New AmericanLibrary, 1970).

Seyyed Hossein Nasr, The Encounter of Man and Nature: The Spiritual Crisis of Modern Man, (London: George Allen and Unwin, 1968).

Seyyed Hossein Nasr, Knowledge and the Sacred, (Edinburgh: Edinburgh Univ.Press, 1980).

Seyyed Hossein Nasr, "The Role of the Tradisional Science in the Encounter of Religion and Science; An Oriental Perspectif", dalam Jurnal Religious Studies, No. 20, Thn. 1984

Seyyed Hossein Nasr, Tradisional Cosmology and Modern Science. Parabola, VIII no. 4, 1983,

A. Mukti Ali, Ilmu Perbandingan Agama di Indonesi, (Bandung: Mizan, 1993). Azyumardi Azra, "Tradisionalisme Nasr: Eksposisi dan Refleksi (Laporan dari Seminar Seyyed Hossein Nasr)", dalam Jurnal Kebudayaan Ulumul Qur'an, No. 4, Vol. IV, Tahun 1993.

Douglas Allen, Structure and Creativity in Religion, (Mouton: The Hague, 1978).

Komaruddin Hidayat, "Upaya Pembebasan Manusia: Tinjauan Sufistik terhadapManusia Modern Menurut Seyyed Hossein Nasr", dalam Dawam Rahardjo, (ed.), Insan Kamil, (Jakarta: PT. Graffiti Press, 1985).

F. Budi Hardiman, "Positivisme dan Hermeneutika: Suatu Usaha untuk Menyelamatkan Subjek", dalam Majalah Basis, (Maret 1991).

F. Budi Hardiman, "IImu-ilmu Sosial dalam Diskursus Modemisme dan PascaModernisme" (Suplemen), dalam Jurnal Kebudayaan, Ulumul Qur'an, No. 4, Vol. V, Tahun 1994.

Fazlur Rahman, "Islamisasi IImu Pengetahuan; Suatu Tanggapan", diterjemahkanoleh Mohammad Shoelhi, dalam Jumalal-Hikmah, No. 7., 1993.

Fazlur Rahman, "Approaches to Islam in Religious Studies", dalam Richard C. Martin, (ed),

Approaches to Islam in Religious Studies, (Tucson: University of Arizona Press, 1985).

Herman Leonard Beck, Filsafat Agama; Ilmu (Perbandingan) Agama dan Metodologi Penelitian Agama, (Makalah untuk Simposium NasionalMetodologi Penelitian Filsafat, Yogyakarta: 27-29 Juni 1991). 
Jalaluddin Rahmat, "Kearifan Perennial; Paradigma Baru Sains, (Makalah untuk Orasi Ilmiah universitas Islam Asy-Syafi'iyah, Jakarta 27 Nopember 1993). Komaruddin Hidayat \& Muhammad Wahyuni Nafis, Agama Masa Depan; Perspektif Perennial, (Jakarta: Paramadina, 1995) 